\title{
CORRELATION STUDY OF DISEASE ACTIVITY SCORE AND SERUM CARTILAGE OLIGOMERIC MATRIX PROTEINLEVELS OF RHEUMATOID ARTHRITIS PATIENTS IN BANDUNG, INDONESIA
}

\author{
NYI MEKAR SAPTARINI ${ }^{1,2 *}$, DAINAR EKA PRATIWI², ELLIN FEBRINA ${ }^{3}$, MARLIA SINGGIH WIBOWOํㅜ, \\ TUTUS GUSDINAR ${ }^{1}$
}

${ }^{1}$ School of Pharmacy Institut Teknologi Bandung, Jl Ganesha 10, West Java, 40132, Indonesia. ${ }^{2}$ Department of Pharmaceutical Analysis and Medicinal Chemistry, Faculty of Pharmacy, Universitas Padjadjaran, Jl Raya Bandung Sumedang km 21, West Java, 45363, Indonesia. ${ }^{3}$ Department of Pharmacology and Clinical Pharmacy, Faculty of Pharmacy, Universitas Padjadjaran Jl Raya Bandung Sumedang km 21, West Java, 45363, Indonesia. Email: nyi.mekar@unpad.ac.id

Received: 19 September 2016, Revised and Accepted: 29 September 2016

ABSTRACT

Objective: This study was designed to determine the correlation between Disease Activity Score (DAS 28) and the serum Cartilage Oligomeric Matrix Protein (COMP) levels in Indonesian Rheumatoid Arthritis (RA) patients.

Methods: The subjects were patients who visit the rheumatology clinic at one governmental hospital in Bandung, Indonesia. DAS was determined by the QxMD Software based on erythrocyte sedimentation rate, and serum COMP levels were determined by enzyme-linked immunosorbent assay. Statistical analysis was conducted with IBM SPSS Statistics 23.

Results: DAS 28 value was $3.36 \pm 0.16$ which indicates the moderate disease activity. Serum COMP levels were $843.80 \pm 35.79 \mathrm{ng} / \mathrm{ml}$ in RA patients and $830.00 \pm 48.92 \mathrm{ng} / \mathrm{ml}$ in normal controls.

Conclusion: There is no correlation between DAS 28 and serum COMP levels in RA patients $(p=0.496$ and rho $=0.129)$.

Keywords: Autoimmune disease, Rheumatoid arthritis monitoring, Cartilage oligomeric matrix protein, Disease activity score 28

(C) 2017 The Authors. Published by Innovare Academic Sciences Pvt Ltd. This is an open access article under the CC BY license (http://creativecommons. org/licenses/by/4. 0/) DOI: http://dx.doi.org/10.22159/ajpcr.2017.v10i1.15251

\section{INTRODUCTION}

Rheumatoid arthritis (RA) is a chronic systemic autoimmune disease which characterized by erosive arthritis in synovial joints symmetrically. It causes the pain, joint damage, malfunction, and decreased quality of life, even deformation [1]. The RA prevalence was various between populations, generally $0.5-1.0 \%$ of the population [2], it was $0.1-0.3 \%$ in Indonesia [3]. Early diagnosis and treatment of patients with RA are important to prevent the joint deformation [4].

Cartilage oligomeric matrix protein (COMP) is a potential biomarker to support the RA diagnosis [5]. COMP was contributed in assembly the collagen fiber type II in cartilage and in cooperation with other matrix proteins which stabilize the collagen network [6]. The serum COMP was correlated with disease activity score (DAS) 28-erythrocyte sedimentation rate (ESR) $(\mathrm{p}<0.05, \mathrm{r}=0.40)$ in the RA early stages [7]. DAS demonstrates the RA stability to determine the appropriate treatment to relieve inflammation associated RA, slow or stop the joint damage that causes pain and deformation [8]. There are no studies about the correlation between DAS 28 and serum COMP levels, so this study was conducted to determine the correlation between DAS 28 and the serum COMP levels in RA patients.

\section{SUBJECTS AND METHODS}

\section{Subjects}

Cross-sectional study with prospective data collection. Subjects were recruited by consecutive sampling method after getting an explanation and signed the informed consent forms. The subject was divided into two groups, RA patients, and normal controls [9]. This study was conducted after approved by the Health Research Ethics Committee of Dr. Hasan Sadikin Hospital, Indonesia, No. LB.04.01/A05/EC/075 III/2016.
The inclusion criteria are:

a. RA patients are the patients of the rheumatology clinic at one governmental hospital in Bandung City, Indonesia.

b. RA patients who meet at least 4 the clinical criteria from 2010 RA classification criteria [10] based on the rheumatologist examination without serology examination.

c. RA patients willing to participate in the present study by signed the informed consent and interviewed.

d. Patient's age was over 18 years old.

The exclusion criteria are:

a. Patients who do not cooperate.

b. History of drug abuse, including alcoholism.

c. Patients with any other major medical disorder, i.e., diabetes mellitus, hypertension, chronic obstructive pulmonary disease, acute or chronic liver disease, acute or chronic kidney disease, tuberculosis, and systemic lupus erythematosus.

Methods

Determination of DAS 28

DAS 28 is calculated by application to calculate in QxMD Software.

\section{Determination of serum COMP levels}

The blood was collected from March to May 2016. The blood was taken from a peripheral vein and placed in a tube without ethylenediaminetetraacetic acid. Blood allowed to stand for 30 minutes to form a coagulant and centrifuged at $3000 \mathrm{rpm}$ for 15 minutes. Serum is separated from the sediment and stored at $-80^{\circ} \mathrm{C}$. Serum COMP levels were determined by the following procedure in the Human COMP/ TSP5 enzyme-linked immunosorbent assay Pair Set (SEK10173) which purchased from Sino Biological Inc. (USA). 
Statistical analysis

Correlation between DAS 28 and serum COMP levels was analyzed using IBM SPSS Statistics 23.

\section{RESULTS}

All patients feel pain in the small joints of the hands, wrists, elbows, knees, and ankles. These facts were accorded with the joints that are common in RA [10]. All patients have worse joint stiffness in the morning and the evening. There was $16.67 \%$ of patients have hand deformities which change the hand function, reduced the grip strength, and complicated daily activities. Most patients (86.67\%) had experienced the knee pain which reduces the ability to walk in long duration which interfering the patient activities. DAS was obtained from data of joint condition, ESR, and subjective patient assessment; then, DAS values were grouped by disease activity range (Table 1). DAS value was $3.36 \pm 0.16(n=30)$, which means the category of moderate disease activity.

There is no correlation between DAS 28 and serum COMP levels $(\mathrm{p}=0.496$ and $\mathrm{rho}=0.129)$

\section{DISCUSSION}

Total RA patients were 80 , but who meet the inclusion criteria only 30 of patients, i.e., 4 of men (13.33\%) and 26 of women ( $86.67 \%)$. All patients were interviewed for age, disease duration, how many joint with definite clinical synovitis (swelling), symmetrical arthritis, pain duration in the morning, drug therapy, medical treatment to reduce the pain such as surgery, and ancestry [9]. The results of present study are consistent with studies by Samanci et al., i.e., the RA incidence in women $(87.43 \%)$ is seven times higher than men [11]. These results are different from the previous study in December 2014 to January 2015 at the same location. The previous results were 24 of patients, i.e., 20 of women (83.33\%) and 4 of men (16.67\%) [9]. The different of number of RA patients who participate in this study showed that the increased awareness of RA patients to support the success of the RA treatment.

Age and gender (Table 2) are the confounding variable, i.e., the bias condition in estimating the variable effects in the RA incidence [12]. The higher RA incidence in women is due to hormones, especially estrogen. Estrogen is a factor that affects the autoimmune diseases, such as RA $[13,14]$. Estrogen and androgen have a very important role in the maturation of growing bones and prevent the losing the bone mass. Over the 30 years old, the female hormone estrogen tends to decrease. It made the estrogen deficiency which stimulates the imbalance of the bone remodeling activity because osteoblasts cannot compensate the osteoclasts work, so bone mass will decrease [15].

Table 1: DAS 28 of RA patients

\begin{tabular}{lll}
\hline DAS 28 range & DAS 28 value & Patient percentage (\%) \\
\hline$<2.6$ & $2.06 \pm 0.43$ & 16.67 \\
$2.6-3.2$ & $2.94 \pm 0.14$ & 30.00 \\
$3.2-5.1$ & $4.00 \pm 0.56$ & 53.33 \\
$>5.1$ & 0 & 0 \\
\hline
\end{tabular}

Values are mean \pm SD $(n=30)$. SD: Standard deviation, RA: Rheumatoid arthritis, DAS: Disease activity score

Table 2: Subject distribution

\begin{tabular}{llllll}
\hline Parameter & \multicolumn{2}{l}{ RA patients } & & & \multicolumn{2}{l}{ Normal controls } \\
\cline { 2 - 3 } \cline { 5 - 6 } \cline { 5 - 6 } & Mean \pm SD & Range & & Mean \pm SD & Range \\
\hline Age (years) & $43.77 \pm 2.04$ & $20-64$ & & $41.23 \pm 2.46$ & $21-60$ \\
Gender $(M / F)$ & $4 / 26$ & - & & $4 / 26$ & - \\
\hline
\end{tabular}

Values are mean \pm SD $(n=30)$. SD: Standard deviation, RA: Rheumatoid arthritis
The age of RA incidence has a wide distribution, but the most common is in 40-50 years old [16]. In this study, the most RA incidence is in 50-59 years old (Fig. 1). These results are different from the literature. We suggested the RA patients are less awareness of the importance of the RA early treatment to avoid the joint damage [17]. The interview data were shown that the patients visit a doctor after realizing that the body movement was abnormal. It was reflected the lack awareness of the RA symptoms. The RA patients were experiencing the severe pain when doing strenuous activities. The RA patients were reduced the pain by taking painkillers, such as paracetamol or diclofenac sodium. In Indonesia, RA was considered as an elderly disease, so there is lacked awareness for health monitoring because of joint pain for people who under 50 years old. In the previous study, the patients with higher education show a higher awareness for health monitoring [9].

Disease duration was used to determine the patient condition when the retrieved data. The shortest disease duration was 3 months, and the longest is 204 months (17 years). The common disease duration was 10-19 months (Fig. 2), and the average was 57.6 \pm 8.8 months. There is a wide range of disease duration, but the patient condition was varied, on the contrary, there was health improvement because of drug compliance. Most RA patients (80\%) have experienced the joint pain for a minimum of three to nine months before a medical checkup. There was $16.67 \%$ of patient have bone deformities because of the retardation of early treatment.

At the first checkup, the patient will request to blood examination to determine the RA symptoms, i.e., ESR and rheumatoid factor. FR was only done on the first examination, whereas ESR was done every month or every three months to determine the inflammatory status. In this study, we were measured the serum COMP levels as a potential RA biomarker, beside FR which already used for RA diagnosis. The serum COMP levels were founded higher in the early stage of RA, so it can be used to determine the RA severity [18]. The cutoff the serum COMP levels in RA patients are still unknown, so we need to compare to the normal controls. The serum COMP levels of RA patients was higher than the normal control (Table 3).

There were $30 \%$ of RA patients were taking the modification joint destruction or pain relief, such as injections and joint surgery. The serum COMP levels in patients who take the injection or surgery were higher than patients who take both injections and surgery (Table 4). It showed that the medical treatment is able to modify the disease condition and support the COMP as a biomarker of RA activity.

All RA patients were taking disease-modifying antirheumatic drugs (DMARDs), nonsteroidal anti-inflammatory drugs, and analgesics. Methotrexate (MTX) was proved to modify the development of joint damage, which resulting decreased COMP levels along with improved joints condition [18]. There were $83.33 \%$ of patients were prescribed MTX, $13.33 \%$ of patients were prescribed a combination of MTX and chloroquine (CQ), $13.33 \%$ of patients were prescribed a combination of MTX and sulfasalazine (SZ), 3.33\% of patients were prescribed a combination of MTX, CQ, and cyclosporin, and 3.33\% of patients were prescribed a combination of MTX, SZ, and azathioprine.



Fig. 1: Distribution of patients among different age groups $(n=30)$ 


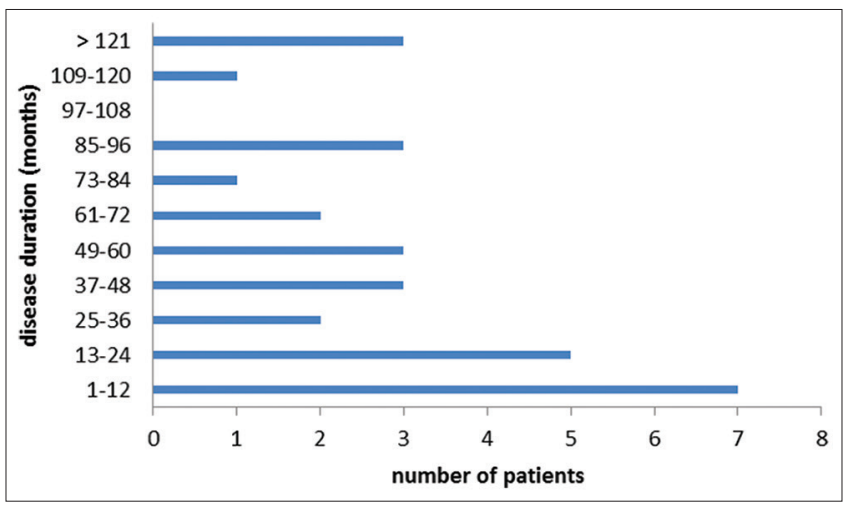

Fig. 2: Distribution of patients among disease duration $(n=30)$

Table 3: Serum COMP levels of RA patients

\begin{tabular}{llll}
\hline Group & $\begin{array}{l}\text { Number of } \\
\text { patients }(\mathbf{n})\end{array}$ & \multicolumn{2}{l}{ Serum COMP levels $(\mathbf{n g} / \mathbf{m L})$} \\
\cline { 3 - 4 } & & RA patients & $\begin{array}{l}\text { Normal } \\
\text { control }\end{array}$ \\
\hline Men & 4 & $665.03 \pm 125.55$ & $790.03 \pm 108.25$ \\
Women & 26 & $871.31 \pm 34.59$ & $836.15 \pm 54.55$ \\
All & 30 & $843.80 \pm 35.79$ & $830.00 \pm 48.92$ \\
\hline
\end{tabular}

Values are mean \pm SD. SD: Standard deviation, RA: Rheumatoid arthritis,

COMP: Cartilage oligomeric matrix protein

Table 4: Serum COMP levels based on medical treatment

\begin{tabular}{lll}
\hline Medical treatment & $\begin{array}{l}\text { Patient } \\
\text { percentage (\%) }\end{array}$ & $\begin{array}{l}\text { CoMP levels } \\
\text { (ng/mL) }\end{array}$ \\
\hline Injection & 10.00 & $997.14 \pm 62.27$ \\
Surgery & 6.67 & $1011.43 \pm 121.22$ \\
Injection and surgery & 13.33 & $772.14 \pm 67.39$ \\
\hline
\end{tabular}

Values are mean $\pm S D(n=9)$. SD: Standard deviation, RA: Rheumatoid arthritis, COMP: Cartilage oligomeric matrix protein

The DMARDs mechanism is to suppress the autoimmune reactivity [19]. Most patients (90\%) were prescribed methyl prednisolone reduce the MTX side, and $33.33 \%$ of patients were given analgesics, such as paracetamol, ibuprofen, diclofenac sodium, and aspirin. Most patients $(90 \%)$ were also given calcium and folic acid to reduce the MTX side effects [20]. The goal of appropriately and routine therapy is to maintain the quality of life and stabilize the disease activity. All patients were felt the pain when they late in medicine consumption. This experience makes patient are compliance to taken the drugs as prescribed. These results are consistent with our previous study in Purwakarta, Indonesia [21].

The t-test for serum COMP levels of RA patients and normal controls showed no difference $(\mathrm{p}=0.821)$. It was because of confounding variables which make the biased results. If the average of DAS 28 was connected to the average serum COMP levels based on disease activity category, the results showed that the higher DAS 28, so the higher serum COMP levels (Fig. 3). However, if DAS 28 and serum COMP levels were connected at any point, the result was no correlation $(\mathrm{p}=0.496$ and rho=0.129). This is because of the DAS 28 calculation variable which involves the ESR that's not specific to RA inflammation. High ESR was predicted obtained from other inflammatory which, experienced by the patient because ESR is a general indication of inflammation in the body [8].

\section{CONCLUSIONS}

There is no correlation between DAS 28 to serum COMP levels in RA patients $(\mathrm{p}=0.496$ and $\mathrm{rho}=0.129)$.

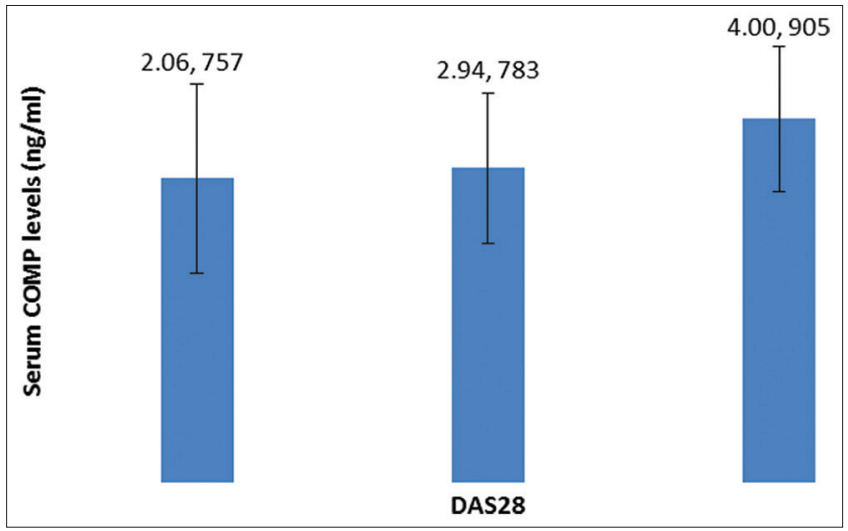

Fig. 3: Distribution of serum cartilage oligomeric matrix protein levels based on disease activity score $28(n=30)$

\section{REFERENCES}

1. Schett G, Hayer S, Zwerina J, Redlich K, Smolen JS. Mechanisms of disease: The link between RANKL and arthritic bone disease. Nat Clin Pract Rheumatol 2005;1(1):47-54.

2. Sacks JJ, Luo YH, Helmick CG. Prevalence of specific types of arthritis and other rheumatic conditions in the ambulatory health care system in the United States, 2001-2005. Arthritis Care Res (Hoboken) 2010;62(4):460-4.

3. Nainggolan O. Prevalensi dan determinan penyakit rematik di Indonesia. Madjalah Kedokt Indones 2009;59(12):588-94.

4. Vittecoq O, Pouplin S, Krzanowska K, Jouen-Beadem F, Me'nard JF, Gayet A, et al. Rheumatoid factor is the strongest predictor of radiological progression of rheumatoidarthritis in a three-year prospective study in community-recruited patients. Rheumatology 2003;42:939-46.

5. Tseng S, Reddi AH, Di Cesare PE. Cartilage oligomeric matrix protein (COMP): A biomarker of arthritis. Biomark Insights 2009;4:33-44.

6. Halász K, Kassner A, Mörgelin M, Heinegård D. COMP acts as a catalyst in collagen fibrillogenesis. J Biol Chem 2007 26;282(43):31166-73.

7. Kawashiri SY, Kawakami A, Ueki Y, Imazato T, Iwamoto N, Fujikawa K, et al. Decrement of serum cartilage oligomeric matrix protein (COMP) in rheumatoid arthritis (RA) patients achieving remission after 6 months of etanercept treatment: Comparison with CRP, IgM-RF, MMP-3 and anti-CCP Ab. Joint Bone Spine 2010;77(5):418-20.

8. NRAS. Know your Disease Activity Score and Stay One Step Ahead of Your RA. UK: Roche Product Ltd., Chugai Pharma UK; 2011

9. Saptarini NM, Wibowo MS, Gusdinar T. Correlation study of age, disease duration, and erythrocyte sedimentation rate among the indonesian rheumatoid arthritis patients. Int J Pharm Pharm Sci 2015;7(11):274-77.

10. Aletaha D, Neogi T, Silman AJ, Funovits J, Felson DT, Bingham CO $3^{\text {rd }}$, et al. 2010 Rheumatoid arthritis classification criteria: An American college of rheumatology/European league against rheumatism collaborative initiative. Arthritis Rheum 2010;62(9):2569-81.

11. Samanci N, Ozdem S, Akbas H, Mutlu D, Gultekin M, Arman M, et al. Diagnostic value and clinical significance of anti-CCP in patients with advanced rheumatoid arthritis. J Natl Med Assoc 2005;97(8):1120-6.

12. Hastono SP. Analisis Data Kesehatan. Depok, Indonesia: Fakultas Kesehatan Masyarakat Universitas Indonesia; 2007.

13. Culoto M, Wilder R. Different roles for androgens and estrogens in the susceptibility to autoimmune rheumatic diseases. Rheum Dis Clin North Am 2000;26(4):825-39.

14. Salem ML. Estrogen, a double-edged sword: Modulation of TH1- and TH2-mediated inflammations by differential regulation of TH1/ TH2 cytokine production. Curr Drug Targets Inflamm Allergy 2004;3(1):97-104

15. Setiyohadi B, Alwi I, Simadibrata M, Setiati M, editors. Ilmu Penyakit Dalam. Jakarta: Pusat Penerbitan Departemen Ilmu Penyakit Dalam Fakultas Kedokteran Universitas Indonesia; 2006.

16. Choy E. Understanding the dynamics: Pathways involved in the pathogenesis of rheumatoid arthritis. Rheumatology (Oxford) 2012;51 Suppl 5:v3-11.

17. Harris E. Clinical features of rheumatoid arthtritis and their clinical significance. Arthritis Res 2002;4 Suppl 2:S1-5.

18. Lindqvist $\mathrm{E}$, Eberhardt $\mathrm{K}$, Bendtzen $\mathrm{K}$, Heinegård $\mathrm{D}$, Saxne $\mathrm{T}$. 
Prognostic laboratory markers of joint damage in rheumatoid arthritis. Ann Rheum Dis 2005;64(2):196-201.

19. Katzung B. Basic and Clinical Pharmacology. 9 ed. United State: McGraw-Hill Comp Inc; 2004.

20. Schuna AA. Rheumatoid arthritis. In: Dipiro JT, Talbert RL, Yee GC, Matzke GR, Wells BG, Posey LM, editors. Pharmacotherapy:
A Pathophysiologic Approach. $7^{\text {th }}$ ed. Singapore: Mc Graw Hill Medical; 2007.

21. Saptarini NM, Wibowo MS, Gusdinar T. Erythrocyte sedimentation rate as an indicator of compliance of rheumatoid arthritis patients: A case study in West Java, Indonesia. Mahidol Univ J Pharm Sci 2016;43(2):55-62 